
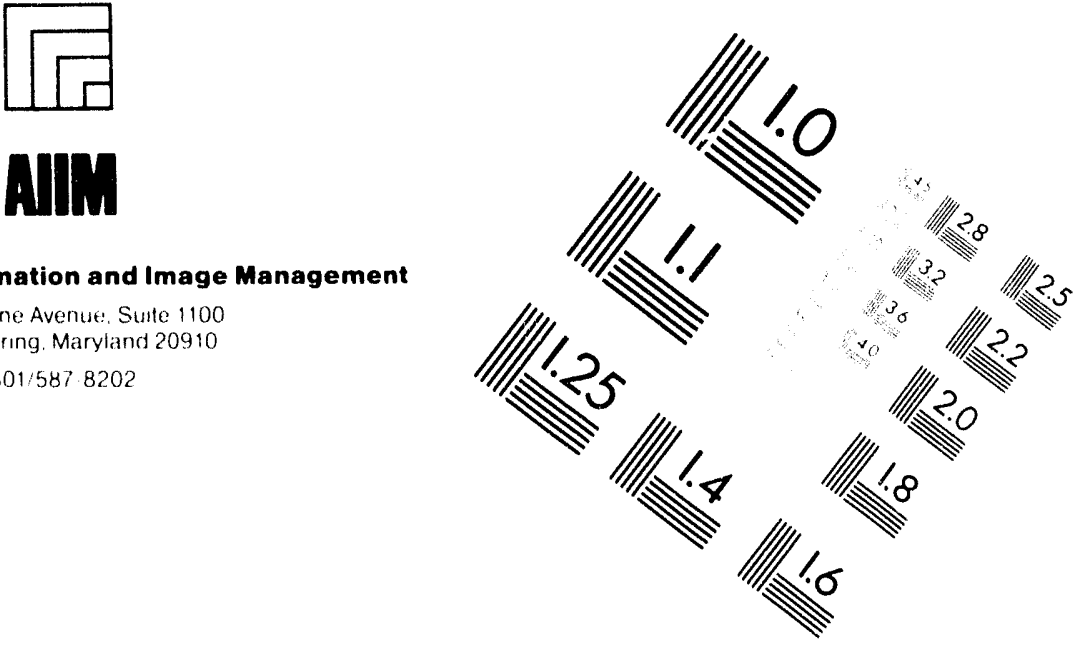

Centimeter

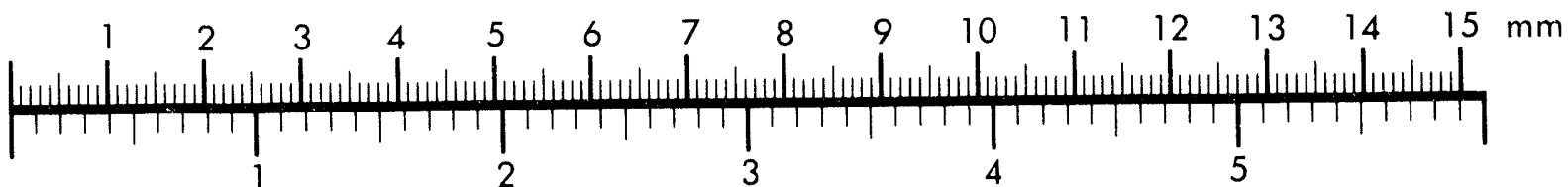
Inches
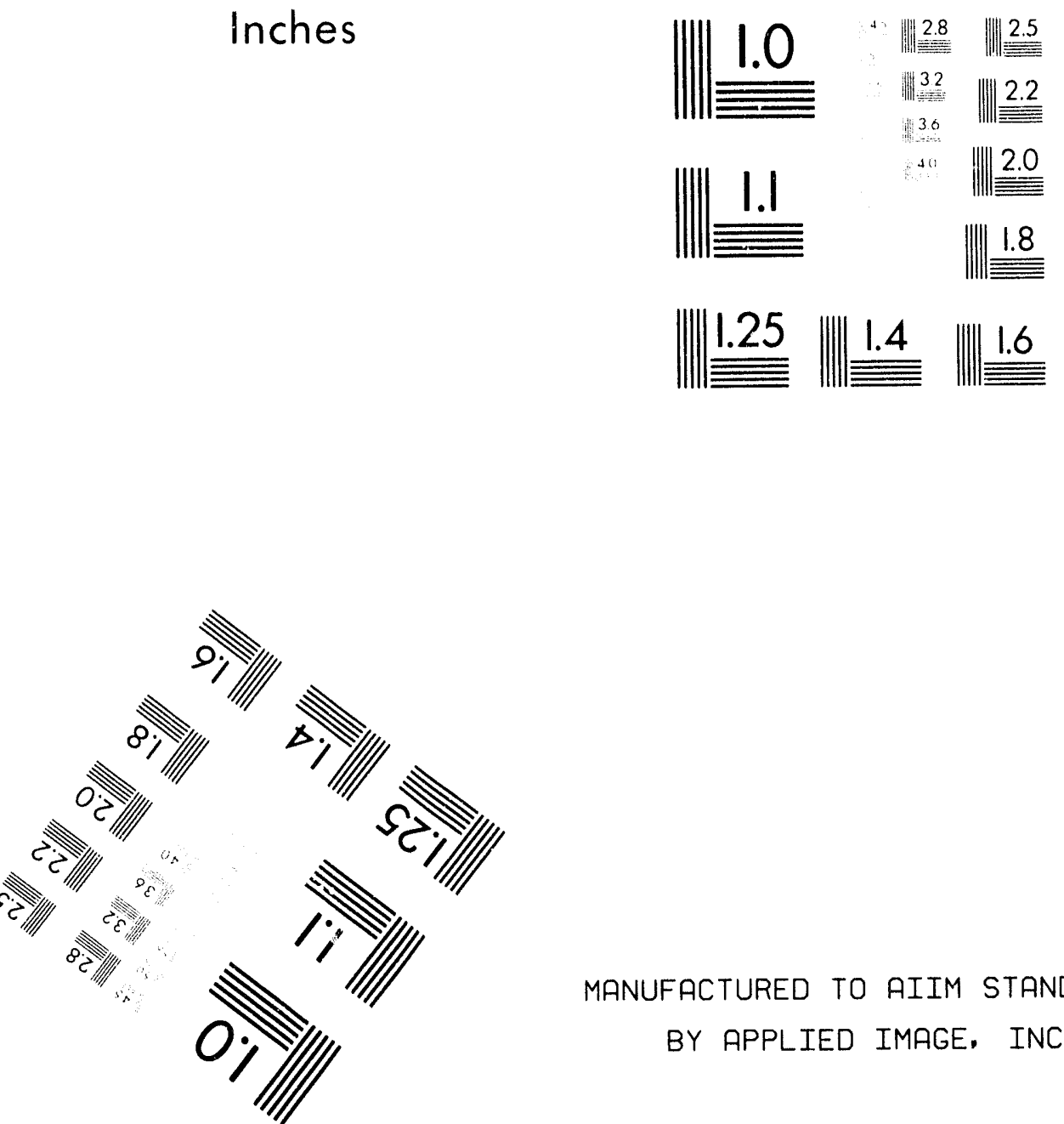

MANUFACTURED TO AIIM STANDARDS

BY APPLIED IMAGE, INC.

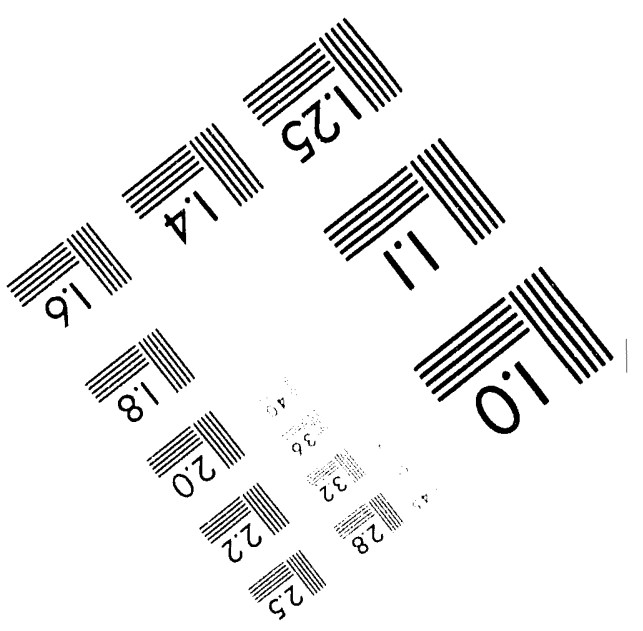



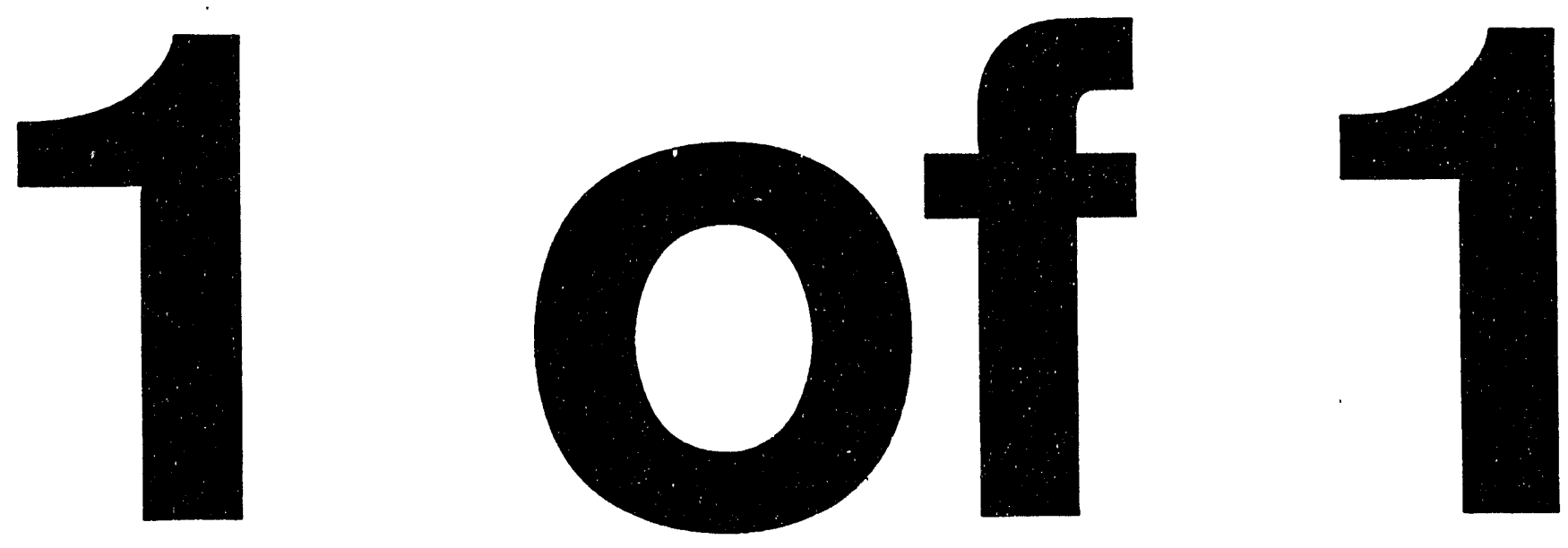


\section{U. S. Department of Energy \\ Radionuclide Air Emissions Annual Report \\ (under Subpart $H$ of 40 CFR Part 61) \\ Calendar Year 1993}

Site Name: Rocky Flats Plant

Operations Office Information

Office: Rocky Flats Office

Address: $\quad$ U. S. Department of Energy

Rocky Flats Plant

P. O. Box 928

Golden, CO 80402-0928

Contact: Jonathan A. Dion

Phone: (303) 966-5904

Allen E. Howard

Phone: (303) 966-5915

Site Information

Operator: EG\&G Rocky Flats, Inc.

Address: Rocky Flats Plant

P. O. Box 464

Golden, CO 80402-0464

Contact: William E. Osborne

Phone: (303) 966-3932

\section{DISCLAIMER}

This report was prepared as an account of work sponsored by an agency of the United States Government. Neither the United States Government nor any agency thereof, nor any of their employees, makes any warranty, express or implied, or assumes any legal liability or responsibility for the accuracy, completeness, or usefulness of any information, apparatus, product, or process disclosed, or represents that its use would not infringe privately owned rights. Referprocess disclosed, or represents that its use wouct, process, or service by trade name, trademark, manufacturer, or otherwise does not necessarily constitute or imply its endorsement, recommanufacturer, or otherwise the United States Government or any agency thereof. The views mendation, or favoring by the United herein do not necessarily state or reflect those of the United States Government or any agency thereof. 


\section{Section I. Facility Information}

\section{P.:

\section{Site Description}

The Rocky Flats Plant (RFP) is part of a nationwide nuclear weapons research, development, and production complex. RFP is operated by EG\&G Rocky Flats, Inc., with oversight by the Rocky Flats Field Office of the U. S. Department of Energy. Previous to February 1992, the primary mission of RFP was the fabrication of nuclear weapons components. RFP fabricated nuclear weapons components from plutonium $(\mathrm{Pu})$, uranium $(U)$, beryllium $(\mathrm{Be})$, and stainless steel. Production activities included metal fabrication and assembly, chemical recovery and purification of process-produced transuranic radionuclides, and related quality control functions. Plutonium weapons operations were curtailed at RFP in 1989 to address safety concerns. Nuclear weapons component production has not and will not resume at RFP. RFP is currently transitioning through deactivation activities. A list of radioactive materials used (or that could be potentially used at RFP) is included in Appendix A.

RFP occupies an area of 6,550 acres (26.5 square kilometers [km²]) in northern Jefferson County, Colorado, approximately 16 miles $(25.7 \mathrm{~km})$ northwest of Denver. Main production facilities are located near the center of RFP within a fenced security area of 384 acres $\left(1.6 \mathrm{~km}^{2}\right)$. The remaining plant area contains limited support facilities and serves as a buffer zone to major production areas. A simplified map of RFP is shown in Figure 1.

Approximately 2 million people live within a 50 -mile $(80.5 \mathrm{~km})$ radius of RFP. Adjacent land use is a mixture of agriculture, open space, industry, and low-density residential housing. Surrounding communities consist of the city of Golden to the south of the plant, the cities of Arvada and Westminster to the east, and the city of Boulder to the north.

The climate at RFP is dry, with cool winters and warm summers. Ellevation and major topographical features significantly influence meteorological transport and dispersion around the site. On days with fair skies and light winds, a broad, regional wind blows up the S. Platte River causing frequent northeasterly winds. Also, winds frequently blow up the local slope at RFP causing southeasterly winds. At night, a shallow drainage wind from the southwest through the northwest often blows during clear skies. Strong, large-scale winds from the west and northwest are also frequent during the day and night.

Annual precipitation averages about 16 inches (40.6 centimeters [cm]) with more than 65 percent occurring between April and August. Average maximum and minimum temperatures range from $41^{\circ} \mathrm{F}\left(5^{\circ} \mathrm{C}\right)$ and $21^{\circ} \mathrm{F}\left(-6.1^{\circ} \mathrm{C}\right)$ in January to $83^{\circ} \mathrm{F}\left(28.3^{\circ} \mathrm{C}\right)$ and $60^{\circ} \mathrm{F}$ $\left(15.6^{\circ} \mathrm{C}\right)$ in July.

RFP is situated at an elevation of about 6,000 feet $(1,829$ meters [m]) on the eastern edge of a geological bench known locally as Rocky Flats. This bench, about 5 miles $(8.1 \mathrm{~km})$ wide in an east-west direction, flanks the eastern edge of the Rocky Mountains. To the east, topography slopes gradually at an average downgrade of 95 feet per mile $(18 \mathrm{~m}$ per $\mathrm{km})$. Approximately 20 miles $(32.2 \mathrm{~km})$ to the west, the Continental Divide rises to elevations exceeding 14,000 feet $(4,267 \mathrm{~m})$. 


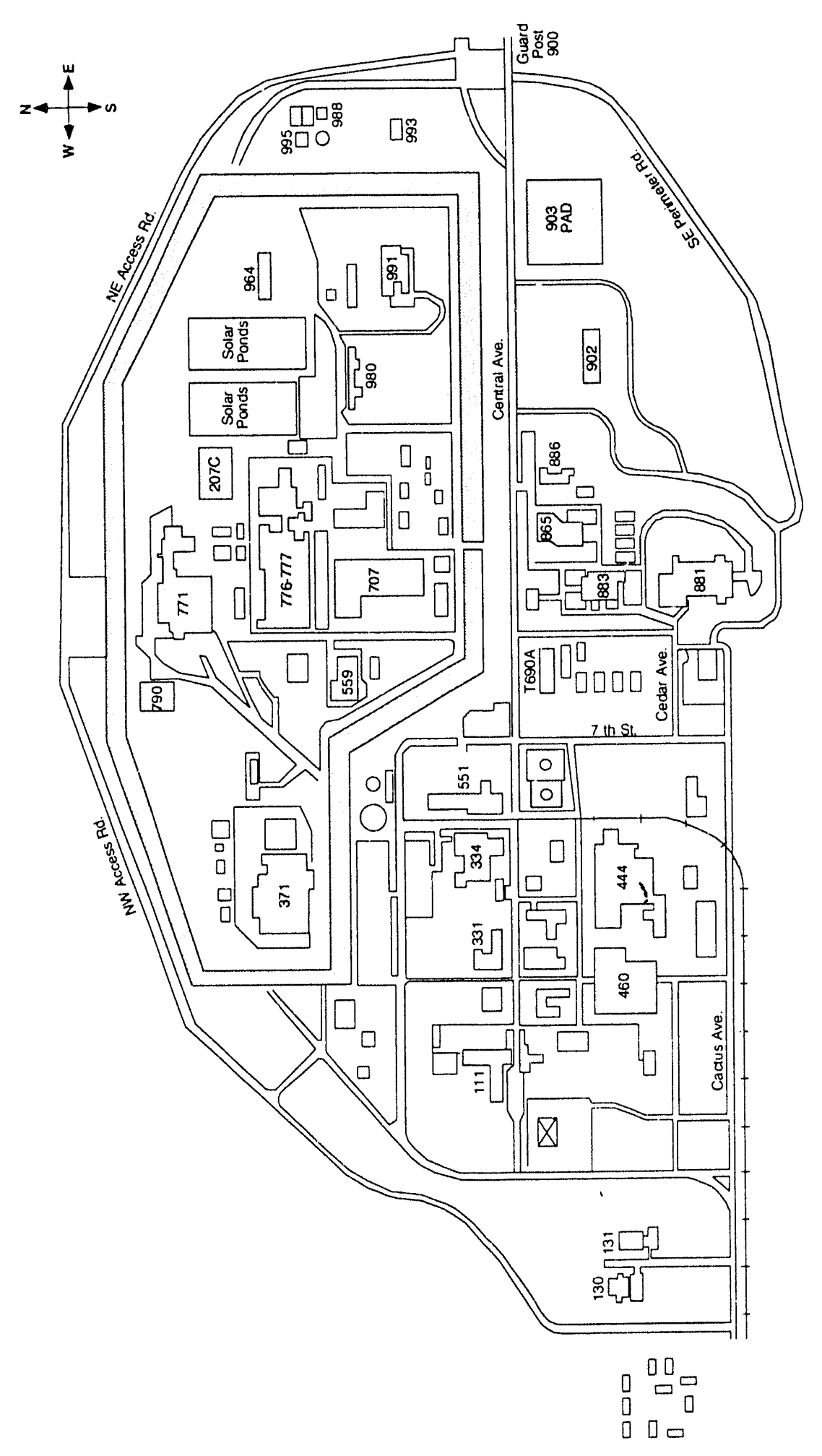

Figure 1 Rocky Flats Plant 
RFP is situated on the Rocky Flats Alluvium (an alluvial fan deposit), varying in thickness from 0 to 100 feet $(30.5 \mathrm{~m})$, providing a gravelly cover over bedrock. Underlying bedrock formations consist primarily of claystone. Seismic activity of the area is low, as is the potential for landslides and subsidence.

Surface drainage generally occurs in a west to east pattern along five ephemeral streams within RFP. North Walnut Creek, South Walnut Creek, and an interceptor ditch (in the Woman Creek drainage) drain the main plant facilities area. Surface water discharges from RFP are diverted around two downstream municipal water supplies: Great Western Reservoir and Standley Lake.

\section{Source Description}

RFP can be roughly divided into halves. The Protected Area, generally located in the north half of the plant, is primarily involved with Pu processing operations. The rest of the plant generally involves $U, B e$, and stainless steel operations. Transuranic material processing can result in particulate matter being released and entrained in air effluent. Exhaust air is cleaned by passing through multiple stages of high efficiency particulate air (HEPA) filters. Because no routine nuclear weapons related processing has occurred since 1989, reported radionuclide point source emissions are believed to be a result of resuspended residual radioactive material in the ventilation systems. Handling of radioactive material at RFP currently involves material consolidation, waste processing, and analytical operations. Most of the total radionuclide air emissions are from diffuse/fugitive area sources. These areas are the result of past radioactive contamination of the environment due to spills or other releases. 


\section{Section II. Air Emissions Data}

RFP continuously samples for radionuclides in the form of particulate matter in 63 ducts and vents downstream of the HEPA filters. Fifty-four of the ducts and vents have potential dose terms that are less than 0.1 millirem (mrem) ( 0.001 sieverts [Sv]) per year, and therefore, require only periodic confirmation of low emissions. Six ducts are sampled for tritium emissions.

Air effluent from Pu processing areas is cleaned by a minimum of four stages of HEPA filters. Air effluent from $U$ processing areas is generally cleaned by a minimum of two stages of HEPA filters. Filters are bench tested prior to installation to ensure that they meet a minimum filter efficiency of 99.97 percent. The filters are tested with a dioctylphthalate aerosol of a nominal 0.3 micrometer particle size. Filters are tested again for leaks following installation into a filter stage/plenum.

Depending on the source, RFP samples for Pu-238, Pu-239/240, americium (Am)-241, U-233/234, U-238, and tritium. RFP also has some quantities of beta- and gamma-emitting sealed sources and low activity analytical stock solutions, powders, and plated sources. Appendix $A$ lists radionuclides that might be associated with RFP and includes these types, although at any one time not all of these radionuclides are necessarily present or in use at RFP. Effluent sampling is not performed for these beta/gamma-emitting radionuclides because of their low activity and/or nondispersable form. These materials are either sealed or nonvolatile for which the best estimate of emissions is essentially zero.

RFP main production facilities cover an area of 384 acres $\left(1.6 \mathrm{~km}^{2}\right)$. The longest and shortest distances between an emission point and the nearest receptor (a residence) are 2.8 miles $(4.5 \mathrm{~km})$ and 2.2 miles $(3.5 \mathrm{~km})$, respectively. The distance from the center of the plant to the nearest receptor is 2.45 miles $(3.9 \mathrm{~km})$. This distance was used as input data in the air dispersion model CAP88-PC, which was used to calculate the maximum effective dose equivalent (EDE) to the public. The following is a breakdown of all point sources. Sources that have an estimated uncontrolled (without HEPA filtration) potential to result in an EDE to the public greater than $0.1 \mathrm{mrem} / \mathrm{yr}(0.001 \mathrm{~Sv})$ require continuous effluent monitoring, and therefore, are listed under major sources. All other point sources are listed under minor sources.

Buildings 123,881 , and 790 , have low-level tritium emissions for which monitoring is not performed (as denoted by an asterisk in the following list). Calibration of tritium detectors, previously performed at multiple locations on plant site, have been consolidated in Building 790. Tritium emissions are estimated using the emission factor contained in Appendix $D$ of 40 CFR 61 . Monitored sources of tritium are denoted by a double asterisk in the following list. 
Point Sources

Major Point Sources
Minimum

Efficiency

Der Filter1.
Distance to Receptor

$\begin{array}{ll}99.97 & 2.8 \text { miles } \\ 99.97 & 2.5 \text { miles } \\ 99.97 & 2.5 \text { miles } \\ 99.97 & 2.6 \text { miles } \\ 99.97 & 2.6 \text { miles } \\ 99.97 & 2.5 \text { miles } \\ 99.97 & 2.5 \text { miles } \\ 99.97 & 2.5 \text { miles } \\ 99.97 & 2.4 \text { miles }\end{array}$

Minor Point Sources

$123^{*}$ (group of 4 )

HEPA
HEPA
HEPA
HEPA
HEPA
HEPA
HEPA
HEPA
HEPA

$\begin{array}{lll}\text { None } & \text { N } / A & 2.7 \text { miles } \\ \text { HEPA } & 99.97 & 2.6 \text { miles } \\ \text { HEPA } & 99.97 & 2.6 \text { miles } \\ \text { HEPA } & 99.97 & 2.6 \text { miles } \\ \text { HEPA } & 99.97 & 2.3 \text { miles } \\ \text { HEPA } & 99.97 & 2.3 \text { miles } \\ \text { HEPA } & 99.97 & 2.3 \text { miles } \\ \text { HEPA } & 99.97 & 2.3 \text { miles } \\ \text { HEPA } & 99.97 & 2.3 \text { miles } \\ \text { HEPA } & 99.97 & 2.3 \text { miles } \\ \text { HEPA } & 99.97 & 2.3 \text { miles } \\ \text { HEPA } & 99.97 & 2.3 \text { miles } \\ \text { HEPA } & 99.97 & 2.3 \text { miles } \\ \text { HEPA } & 99.97 & 2.3 \text { miles } \\ \text { HEPA } & 99.97 & 2.4 \text { miles } \\ \text { HEPA } & 99.97 & 2.8 \text { miles } \\ \text { HEPA } & 99.97 & 2.8 \text { miles } \\ \text { HEPA } & 99.97 & 2.8 \text { miles } \\ \text { HEPA } & 99.97 & 2.8 \text { miles } \\ \text { HEPA } & 99.97 & 2.5 \text { miles } \\ \text { HEPA } & 99.97 & 2.5 \text { miles } \\ \text { HEPA } & 99.97 & 2.5 \text { miles } \\ \text { HEPA } & 99.97 & 2.5 \text { miles } \\ \text { HEPA } & 99.97 & 2.5 \text { miles }\end{array}$

1 mile $=1.609 \mathrm{~km}$ 


\begin{tabular}{|c|c|c|c|}
\hline & & $\begin{array}{l}\text { Minimum } \\
\text { Efficiency } \\
\text { per Filter }\end{array}$ & \\
\hline Minor Point Sources (cont.) & Type Control & & Distance to Receptor \\
\hline 707-R21A & HEPA & 99.97 & 2.5 miles \\
\hline $707-\mathrm{R} 21 \mathrm{~B}$ & HEPA & 99.97 & 2.5 miles \\
\hline 707-R22A & HEPA & 99.97 & 2.5 miles \\
\hline 707-R22B & HEPA & 99.97 & 2.5 miles \\
\hline 707-R23A & HEPA & 99.97 & 2.5 miles \\
\hline 707-R23B & HEPA & 99.97 & 2.5 miles \\
\hline $707-R 24 A$ & HEPA & 99.97 & 2.5 miles \\
\hline $707-\mathrm{R} 24 \mathrm{~B}$ & HEPA & 99.97 & 2.5 miles \\
\hline 707-R25A & HEPA & 99.97 & 2.5 miles \\
\hline $707-\mathrm{R} 25 \mathrm{~B}$ & HEPA & 99.97 & 2.5 miles \\
\hline 707-R26A & HEPA & 99.97 & 2.5 miles \\
\hline 707-R26B & HEPA & 99.97 & 2.5 miles \\
\hline 707-R27A & HEPA & 99.97 & 2.5 miles \\
\hline $707-\mathrm{R} 27 \mathrm{~B}$ & HEPA & 99.97 & 2.5 miles \\
\hline $707-R 45 A$ & HEPA & 99.97 & 2.5 miles \\
\hline $707-\mathrm{R} 45 \mathrm{~B}$ & HEPA & 99.97 & 2.5 miles \\
\hline 707-R46A & HEPA & 99.97 & 2.5 miles \\
\hline 707-R46B & HEPA & 99.97 & 2.5 miles \\
\hline 771-CMA & HEPA & 99.97 & 2.6 miles \\
\hline 771-CRM8 & HEPA & 99.97 & 2.6 miles \\
\hline $771 \cdot$ CRM 10 & HEPA & 99.97 & 2.6 miles \\
\hline $776-202$ & HEPA & 99.97 & 2.5 miles \\
\hline $776-205^{* *}$ & HEPA & 99.97 & 2.5 miles \\
\hline $776.206^{* *}$ & HEPA & 99.97 & 2.5 miles \\
\hline $776-250$ & HEPA & 99.97 & 2.5 miles \\
\hline $776-251^{* *}$ & HEPA & 99.97 & 2.5 miles \\
\hline $776-252^{* *}$ & HEPA & 99.97 & 2.5 miles \\
\hline 778-LDY & HEPA & 99.97 & 2.5 miles \\
\hline $779-729$ & HEPA & 99.97 & 2.4 miles \\
\hline $790^{*}$ & None & $N / A$ & 2.6 miles \\
\hline $991-985$ & HEPA & 99.97 & 2.2 miles \\
\hline $991-\mathrm{MAl}$ & HEPA & 99.97 & 2.2 miles \\
\hline
\end{tabular}

Following are the total 1993 radionuclide stack effluent emissions from RFP. These totals include estimated emissions from nonmonitored locations.

Point Source

Radionuclide

$\mathrm{Pu}-238$

$\mathrm{Pu}-239 / 240$

Am -241

$U-233 / 234$

$U-238$

Tritium

\begin{tabular}{|c|c|}
\hline Annual Que & antity \\
\hline 1.1 & E-08 \\
\hline 1.5 & $E-07$ \\
\hline 1.6 & E-07 \\
\hline 7.0 & $E-07$ \\
\hline 1.1 & $E-06$ \\
\hline 3.7 & E-03 \\
\hline
\end{tabular}

Annual Quantity (Curies)

E-08

16 E-07

1.1 E-06

3.7 E-03

1 Curie $(\mathrm{Ci})=3.7$ E 10 becquerels $(\mathrm{Bq})$ 


\section{Nonpoint Sources}

RFP has many sources of potential diffuse radionuclide emissicns. The boundaries of these sources are becoming more defined or characterized with respect to radionuclide soil concentrations. Efforts continue to quantify these soil characteristics through site investigations.

A listing of nonpoint sources (diffuse sources of radionuclide emissions) and their distance to the receptor are listed in Appendix $\mathrm{C}$. The following is a listing of the estimated diffuse emissions by isotope. These emissions are based on soil samples analyzed for pertinent isotopes. The listing includes the typical uranium isotopes that were not available for the 1992 report. Plutonium contaminants (i.e., Pu-238, 241, 242) are not included in this years report since each contributes less than 10 percent of the total effective dose equivalent (40 CFR $61.93(b)(4))$; soil samples are not analyzed for these isotopes.

Non-Point Source

Radionuclide

$\mathrm{Pu}-239 / 240$

Am-241

$U-233 / 234$

$U-235$

$U-238$
Annual Quantity (Curies)

3.4 E-05

5.7 E-06

1.1 E-06

$2.2 \quad E-07$

$3.0 \quad E-08$

1 Curie $(\mathrm{Ci})=3.7$ E 10 becquerels $(B q)$

The shortest distance between an RFP radionuclide release point and farmland producing agricultural products is as follows:

- cropland (wheat) -- 1.25 miles $(2.0 \mathrm{~km})$;

- beef cattle -- 1.8 miles $(2.9 \mathrm{~km})$; and

- dairy cows -- 5.6 miles $(9.0 \mathrm{~km})$. 
Section III. Dose Assessments

\section{Description of Dose Model}

RFP used the dose model CAP88-PC (Version 1.0) for calculating the EDE to the public.

\section{Summary of Input Parameters}

RFP wind rose data were entered into the model and are available in the compliance reports in Appendices B and C. The 1993 total precipitation at RFP was 12.1 inches $(30.7 \mathrm{~cm})$ with an average annual temperature of 45.7 of $\left(7.6^{\circ} \mathrm{C}\right)$. A lid height of 4,610 feet $(1,405 \mathrm{~m})$ was used in the model. CAP88-PC default values were used for the activity median aerodynamic diameter (AMAD) and solubility class. Urban agricultural data was used in the calculation.

\section{Point Sources}

The nearest receptor is a residence 2.45 miles $(3,942$ meters) from the center of the RFP production area. This distance was used as input data for the dispersion model. The plant was divided into quadrants for simplicity. A stack height and diameter for each quadrant and the corresponding emissions for each quadrant were entered into the dispersion model. The stack height and diameter for the stack with the highest emission in a particular quadrant was entered for that quadrant. These data are available in the compliance report in Appendix B.

\section{Non-Point sources}

Validated radionuclide surface soil data was used to develop a set of estimated concentration isopleths spanning the entire plant site. Source areas (Individual Hazardous Substance Sites [IHSS's] and Operable Unit [OU] areas) are encompassed by these various isopleths. Data retrieved from the Rocky Flats Environmental Data Base System (RFEDS) was merged with the surface sampling locations that reside in the Geographic Information System (GIS). The result was a fixed formatted file containing the " $X$ " and " $Y$ " coordinates of each soil sample.

Estimated soil concentration isopleths were generated using Dynamic Graphics Interactive Surface Modeling (ISM) software. An interpolated grid was created from the coordinate data file using an inverse distance weighting mathematical algorithm. A smoothing factor was applied to the grid in order to create generalized contour lines. Once the isopleths were created, ARC/Info GIS software was used to determine the area of each isopleth, the centroid of each isopleth, and the distance from each centroid to the receptor. This information was necessary to model the diffuse emissions in CAP88-PC.

CAP88-PC models an area source as a point source at the center of the area source. Each isotopic isopleth was modeled individually due to the limitations of the computer code. CAP88$\mathrm{PC}$ calculates the dose at a given distance for each of the 16 compass directional sectors. The maximum dose from all of the sectors is printed on the first page of the generated synopsis report. This dose is misleading if the receptor does not lie in the sector with the maximum dose. In order to be realistic, the dose for each isopleth was chosen for the respective sector in which the receptor lies and hand written on the front page of each synopsis report. The dose from all of the isotopic isopleths were summed to obtain the total dose to the receptor. 
All of the individual isopleth dose calculations can be found in Appendix C. Appendix $C$ contains five isotopic source term maps, calculations, and summary modeling reports. Appendix $D$ contains the research paper Resuspension of Soil Particles From Rocky Flats Containing Plutonium Particles that discusses the diffuse resuspension rate used in the calculations. An exit velocity of 0 feet per second (s) for resuspended particles was used in the dose model.

\section{Compliance Assessment}

\section{Point Sources}

Effective Dose Equivalent:

1.7 E-05 mrem (1.7 E-07 mSv)

Location of Maximally

Exposed Individual:

Southeast of RFP, corner of Indiaria Street and 96th Street

Non-Point Sources

Effective Dose Equivalent:

1.6 E-03 mrem (1.6 E-05 mSv)

Location of Maximally

Exposed Individual:

Southeast of RFP, corner of Indiana Street and 96th Street

\section{Certification}

I certify under penalty of law that I have personally examined and am familiar with the information submitted herein and based on my inquiry of those individuals immediately responsible for obtaining the information, 1 believe that the submitted information is true, accurate, and complete. I am aware that there are significant penalties for submitting false information including the possibility of fine and imprisonment. (See $18 \mathrm{U}$. S. C. 1001.)

M. N. Silverman

Manager, Rocky Flats Field Office

Department of Energy

Signature: Date: 


\section{Section IV. Additional Information}

There were no unplanned releases of radionuclides to the atmosphere from RFP during 1993.

In July, 1993 a scabbling device was used to decontaminate two concrete docks on the east side of Building 883. The scabbling device incorporates a high-performance vacuum/waste packaging unit in conjunction with pneumatically operated scabblers and needle scalers that safely remove contaminated material from concrete and steel surfaces. Dust and debris are captured at the cutting tool surface and filtered through a high efficiency particulate air filter. Approximately $1.9 \mathrm{E}-05 \mathrm{Ci}$ of $\mathrm{U}-238$ were removed from the concrete docks. Estimated emissions, based on 40 CFR 61, Appendix D, emission and adjustment factors, was $1.9 \mathrm{E}-07 \mathrm{Ci}$ of $U$-238. This amount was included in RFP's total emissions and modeled. 


\section{Supplemental Information}

- The collective effective dose equivalent for 1993 releases was 2.9E-03 person-rem for point sources and 1.2 E-01 person-rem for diffuse sources.

EPA Region VIII issued EG\&G Rocky Flats, Inc., an Administrative Compliance Order (ACO) on March 3, 1992, for alleged noncompliance with the monitoring protocol of 40 CFR 61 , Subpart $H$. EG\&G submitted all required information to the EPA by December 18, 1992. The information detailed RFP compliance with 61 of 63 radionuclide effluent air emission ducts and associated sampling systems. Based on the results, RFP found that only 9 of the 63 emission points require continuous effluent air monitoring. The balance of the locations require only periodic confirmation of low emissions. Of the nine locations, two locations do not have flow rate measurement ports that meet EPA Reference Method 1. RFP requested alternate sampling methodology approval for these two locations and EPA Region VIII accepted the RFP proposal for one location. EG\&G installed new ports at the other location to meet EPA Reference Method 1 and performed EPA Reference Method 2 for compliance.

In September 1993, EPA Region VIII issued EG\&G a request for information under Section 114 of the Clean Air Act. EPA believed that the additional information was necessary to complete their review and issue a compliance determination. The information was supplied to the EPA in two submittals. EPA continues to review all submitted information. To the extent EPA concurs with EG\&G's assessment, compliance will be demonstrated.

RFP handles only small quantities of Radon-226, U-232, and Thorium-232 as stock analytical solutions. This information is detailed in Appendix A.

The quality assurance (QA) program described by Apperidix B, Method 114, is in-place. 
- The following are the 1993 radionuclide releases from RFP by building.

Radionuclide Release (Ci)

\begin{tabular}{|c|c|c|c|c|c|c|}
\hline Building & $P u-238$ & $P u-239 / 240$ & Am-241 & $U-233 / 234$ & $\underline{U}-238$ & $\underline{H-3}$ \\
\hline 123 & 0 & 0 & 0 & 0 & 0 & 8.6E-09 \\
\hline 371 & 2.6E-10 & $3.8 E-09$ & $9.4 E-09$ & $2.7 E-08$ & $3.0 E-08$ & 0 \\
\hline 374 & $5.6 E-10$ & 8.3E-09 & 8.7E-09 & $1.1 \mathrm{E}-08$ & $1.5 E-08$ & 0 \\
\hline 444 & 0 & 0 & 0 & $5.1 E-08$ & $6.0 E-08$ & 0 \\
\hline 447 & 0 & 0 & 0 & $2.9 E-08$ & $4.1 E-08$ & 0 \\
\hline 559 & $4.7 E-10$ & $3.4 E-09$ & $1.9 E-09$ & $1.8 E-08$ & $2.5 E-08$ & 0 \\
\hline 707 & $2.0 E-09$ & $4.3 E-08$ & $3.3 E-08$ & $8.5 E-08$ & 1.4E-07 & $1.9 E-05$ \\
\hline 771 & $1.4 E-09$ & $1.7 E-08$ & $2.1 E-08$ & $5.0 E-08$ & $7.7 E-08$ & 0 \\
\hline 774 & $2.3 E-10$ & $3.8 E-10$ & $3.7 E-10$ & $-4.0 E-11$ & $8.7 E-10$ & 0 \\
\hline 776 & $6.5 E-10$ & $1.6 E-08$ & $1.3 E-08$ & $4.2 E \cdot 08$ & $5.0 E-08$ & $2.5 E-03$ \\
\hline 778 & $4.9 E-10$ & $1.2 E-08$ & $2.9 E-09$ & 5.1E-09! & $1.9 E-08$ & 0 \\
\hline 779 & $8.5 E-10$ & $1.1 \mathrm{E}-0^{\circ}$ & $1.1 E-08$ & $3.1 E-08$ & 2.9E-08 & $1.2 E-03$ \\
\hline 790 & 0 & 0 & 0 & 0 & 0 & $3.5 E-06$ \\
\hline 865 & 0 & 0 & 0 & $4.8 E-08$ & $5.2 E-08$ & 0 \\
\hline 881 & 4.3E.09 & $3.1 E-08$ & $5.5 E-08$ & $2.1 E-07$ & 2.3E-07 & $5.8 E-08$ \\
\hline 883 & 0 & 0 & 0 & $9.6 E-08$ & $3.1 E-07$ & 0 \\
\hline 886 & $2.6 E-11$ & $1.7 E-09$ & $7.8 E-10$ & $3.7 E-09$ & $6.1 E-09$ & 0 \\
\hline 889 & $-2.4 E-12$ & $5.5 E-10$ & $1.1 E-10$ & $-4.5 E-09$ & $-3.1 E-09$ & 0 \\
\hline 991 & $2.9 E-10$ & $1.4 \mathrm{E}-09$ & $1.8 E-09$ & 5.9E-09 & $7.4 E-09$ & 0 \\
\hline
\end{tabular}



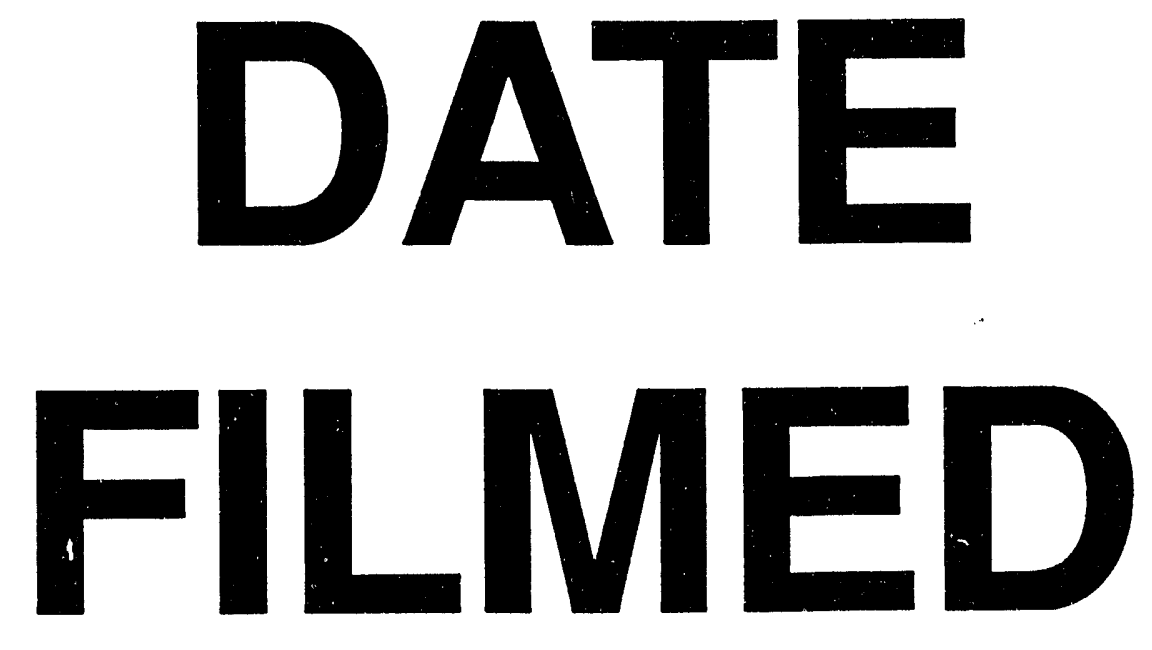

$6 / 28 / 94$
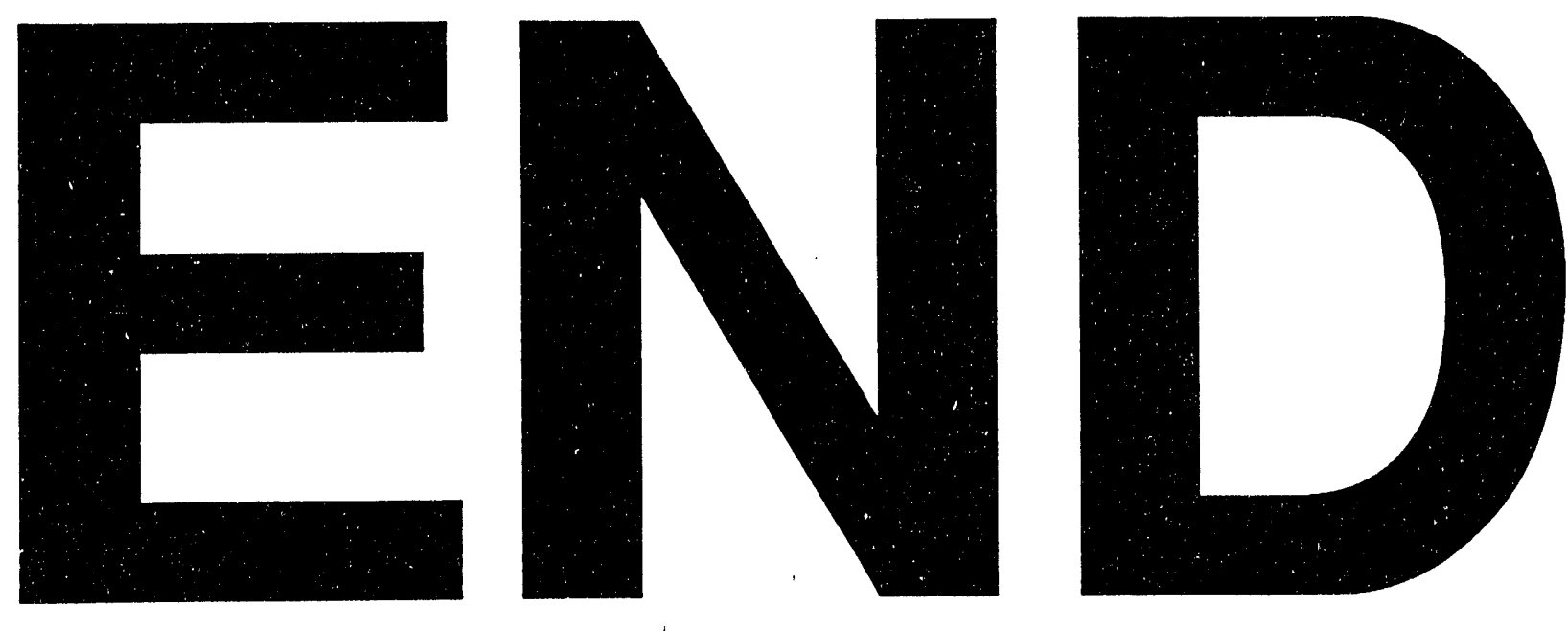
